\title{
From ocean formation to mountain evolution in alpine-type orogens
}

\author{
Christian Sue $^{1}{ }^{\mathbb{D}} \cdot$ Stefan $^{\text {M. Schmid }}{ }^{2}$
}

Received: 18 March 2017/ Accepted: 30 March 2017/Published online: 26 April 2017

(C) Swiss Geological Society 2017

The 12th Alpine Workshop, organized by Christian Sue, Gianreto Manatschal and Raymond Cirio, was held in the Montgenèvre resort, located next-door to one of the bestpreserved ocean floor sequences exposed in the Western Alps, known as the Chenaillet ophiolite. As all the previous bi-annual series of Alpine workshops this conference was again held in a friendly and stimulating atmosphere.

Before introducing the collection of papers received after the conference we take the opportunity to mention the locations and dates of the previous conferences. The first Alpine Workshop conference was held in Grenoble (France) in 1993, and was followed by Basel (Switzerland) in 1995, Oropa (Italy) in 1997, Tübingen (Germany) in 1999, Obergurgl (Austria) in 2001, Sopron (Hungary) in 2003, Opatja (Croatia) in 2005, Davos (Switzerland) in 2007, Cogne (Italy) in 2009, Saint-Florent (Corsica, France) in 2011, Schladming (Austria) in 2013, and Montgenèvre-Briançon (France) in 2015.

In 2013, this informal series of conferences acquired an official character, being held under the auspices of the European Geosciences Union for the first time under the name

Preface to Part 1 of the Swiss Journal of Geosciences, Volume 110, Number 2. This part consists of a collection of papers presented at the 12th Alpine Workshop (third EGU-sponsored Emile Argand Conference on Alpine Geological Studies) held in MontgenèvreBriançon (France) on 13-19 September 2015.

Stefan M. Schmid

stefan.schmid@unibas.ch

Christian Sue

christian.sue@univ-fcomte.fr

1 Université de Franche-Comté, Chrono-environnement, 16 route de Gray 2503, Besançon, France

2 Institute of Geophysics, ETH Zürich, Sonneggstrasse 5, 8092 Zurich, Switzerland
"Emile Argand Conference on Alpine Geological Studies", in honour of the famous Swiss geologist, Emile Argand (1879-1940), who first linked plate tectonics and dynamics of orogeny (e.g. Argand 1924). The aim of the conferences is to promote the discussion of new data and interpretations based on studies addressing the structural, tectonic, metamorphic and sedimentary evolution of the Alps, and adjacent Mediterranean Alpine-type orogens, in an informal and friendly atmosphere by bringing senior researchers together with young scientists, including numerous $\mathrm{PhD}$ students.

A first group of papers arising from the 12th Alpine Workshop focuses on a topic that recently received a lot of attention by the international community, including oil companies working in off-shore areas of passive margin environments. Such environments are characterised by highly extended continental crust grading into adjacent oceanic areas formed along slow spreading (Atlantic) type ridges, the fossil equivalents of which are exposed in the Alps. The paper by $M$. E. Epin, G. Manatschal and M. Amann analyses well preserved structures still inherited from rift-related tectonism in an area of intense Alpine deformation related to the subsequent closing of Alpine Tethys. Their case study carried out in the Err and Platta nappes of southeastern Switzerland, representing an ocean-continent transition, focuses on the discussion as to how much rift-inheritance controls the architecture of a collisional orogen such as the Alps. They point out that retro-deformation of Alpine shortening inevitably results in a template of non-layer cake rift structures in the internal most parts of a collisional orogen. N. Incerpi, L. Martire, G. Manatschal and S. M. Bernasconi also present a study carried out in the same area; they specifically focus on hydrothermal fluid circulation in pre- and syn-tectonic sediments associated with detachment faults in order to improve our knowledge on thermal regimes in hyperextended continental margins. Their study reveals the complexity of the evolution of 
hyperextended continental rift domains and, at the same time, highlights the importance of studying fossil analogues in order to better constrain and understand present-day passive margin features. T. Mateeva, G. A. Wolf, G. Manatschal, S. Picazo, N. $J$. Kuzmir and J. Wheeler analysed the content of organic matter in the Totalp serpentinites of southeastern Switzerland, formed at another location preserving a fossil ocean continent transition zone. They provide evidences for the preservation of traces of organic matter originally deposited in a reducing marine environment in serpentinized mantle rocks and overlying sediments. Although they searched for biomarkers or molecular remains of former living organisms they found no indication that the organic matter was generated from methanotrophic bio-systems. The paper of M. R. Renna, R. Tribuzio, A. Sanfilippo and M. Tiepolo focuses on a geochronological analysis of yet another continent-near ophiolitic unit, the Balagne ophiolite in Corsica, in dating oceanic lower crustal plagiogranite, as well as associated quartzo-feldspathic clastic sediments. They found surprisingly young ages of crystallization for the plagiogranites (Oxfordian) suggesting that these rocks could possibly represent one of the youngest pieces of lower oceanic crust found in the Alpine orogen, while the quartzo-feldspathic clastics from the nearby continent revealed Permian ages.

A classical and very detailed structural-petrological field study is presented by $F$. Kirst, who studied multiple reactivations of the basal thrust zone of the Dent Blanche continental klippe overlying the Piedmont-Liguria ophiolites. Repeated shearing of the fault rocks associated with this tectonic contact occurred during a very long time interval (43-32 Ma) under ductile conditions. The shearing took place initially under blueschist facies conditions, with changes from thrusting to normal sense shearing and back to thrusting under greenschist facies conditions, before being affected by normal faulting again, after $32 \mathrm{Ma}$, under semi-brittle to brittle conditions.

Two papers investigate the role of inherited pre-orogenic faulting and paleogeographical disposition on the early stages of orogeny using alternative approaches. A. Bauville and S. M. Schmalholz present an inspiring numerical modelling study that investigates the initiation of shear zones in the Helvetic nappes. They demonstrate that the differences in viscosity between crystalline basement and the sediments found in half-grabens play a major role by initiating strain localization during nappe formation, while rheological softening mechanisms might have further intensified subsequent shear localization. For the purpose of comparison with the Alps $C$. Bell and R. Butler present a study that analyses 3D seismic sections and drill holes from the Kamchia basin (Black Sea), caught between the Balkan orogen and the relatively mildly deformed Moesian platform being relatively mildly deformed. Their study provides key observations focusing on the role of the transition between weakly and strongly rifted continental crust during early stages of orogeny. Such observations cannot be made in an orogenic system such as the Alps proper, whose internal zones have subsequently become too strongly deformed.

Another two papers, again very contrasting in terms of methodology, analyse present-day and late-stage brittle faulting in the Alps and their foreland, respectively. $N$. Vouillamoz, J. Mosar and N. Deichmann present a seismic hazard assessment of a very prominent line source of seismic activity: the Fribourg lineament hosted in the molasse foreland of the Alps. They use a novel approach by monitoring very low magnitude events and dense spacing of stations (down to $\mathrm{ML}=-2.0$ ). Integration of the data in a 3D model provides evidence that this lineament is only active within the sedimentary cover; but the authors cannot exclude future activity also in the basement that could potentially lead to a magnitude 6 earthquake. For the first time $A$. Bertrand and $C$. Sue studied late-stage (Miocene) brittle faulting at the scale of the entire Alpine chain by providing overall homogeneous orogen-scale mapping of late Alpine brittle deformations, combined with thermochronological data. They found that orogen-parallel extension was surprisingly stable at the scale of the orogen and discuss a possible coupling of this extension with the directions of mantle flow as revealed by SKS anisotropy axes, also oriented subparallel to the orogen.

Finally, S. M. Schmid, E. Kissling, T. Diehl, D. J. J. van Hinsbergen and $G$. Molli provide another orogen-scale study that addresses the kinematics of the formation of the arc of the Western Alps, based on existing structural data combined with a series of new and revised geophysical transects along the entire arc, and on the results of a 3D-model of p-wave velocities derived from crustal tomography. Their discussion of the Alps-Apennines transition suggests that substantial parts of the Northern Apennines formerly suffered Alpinetype shortening associated with an E-dipping Alpine subduction zone being back-thrusted to the NE during Apenninic orogeny, after a reversal in subduction polarity that commenced in the Oligocene.

The editors of this collection of papers gratefully acknowledge the colleagues who kindly accepted to review the manuscripts, and who provided accurate and fruitful comments. We also warmly thank the chief editor of the Swiss Journal of Geosciences, A. G. Milnes, who helped us to organize this special volume and to actually publish it, as was announced at the Montgenèvre-Briancon Alpine Workshop. Finally, we wish to dedicate this collection of papers to the memory of Marco Beltrando.

\section{Reference}

Argand, E. (1924). La Tectonique de l'Asie. In Extrait du Compterendu (Ed.), du XIIIe Congrès Géologique International de Bruxelles (pp. 171-372). Liège: Imprimerie Vaillant-Carmanne. 